\title{
The Application and Development of VR Technology in the Practical Teaching of College Ideological and Political Education
}

\author{
Mian Chen ${ }^{1}$, Linyan Luo ${ }^{2}$ \\ ${ }^{1}$ Organization Department, Kunming Metallurgy College, Kunming 650033, China \\ ${ }^{2}$ Public Affairs Department, Kunming Metallurgy College, Kunming 650033, China
}

Keywords: VR technology; colleges and universities; ideological politics; practical teaching; a virtual environment

\begin{abstract}
With the rapid development of Internet technology, the application of VR technology has become an important sign of the development of the times. Against this background, education not only faces new opportunities but also new challenges. The application of VR technology can not only enrich the content of education, but also strengthen the control of education in the discourse right of students. At the same time, it has a great influence on the establishment of all-staff, all-directional and whole-process ideological and political education, realizing the comprehensive integration of the real and virtual education environment. Based on VR technology, education should establish the education mechanism of the other party's participation from the macro level, and gradually strengthen the vocational information literacy of teachers and students' sense of participation in ideological and political learning.
\end{abstract}

\section{Introduction}

VR technology was first proposed in the 1980s. It is based on graphics computing, data processing and logic control, as well as data development. At present, education teaching of ideological and political science is mainly applied to the graphic calculation section.

Ideological and political theory class is the main task for the student to carry on the system of Marxist theory and ideological and moral education, help students to set up scientific world view, serve the people heart and soul of the outlook on life, the selfless dedication of the values and the socialism faith, constantly improve their political ideological consciousness, cultivate new beauty, intelligence and physique full scale development "four haves". In order to do a good job in teaching ideological and political theory courses and enhance their appeal and appeal, it is necessary to change teaching concepts, update teaching methods and adopt modern teaching methods. The application of modern education technology in the teaching of ideological and political theory courses is a new way to reform the teaching methods and methods of current ideological and political theory courses, and one of the important measures to actively adapt to the needs of social development and meet the challenges of the information age. If teachers can correctly, appropriately and timely use modern education technologies such as multimedia to assist teaching in their teaching work, they will inject new vitality and vitality into the ideological and political theory course, which will greatly promote the teaching reform and optimize the teaching process, so as to improve the teaching quality and effect.

\section{The Application of VR Technology in the Practical Teaching of College Ideological and Political Education}

Graphic computing is a new method of human-computer interaction with the help of computer and the latest sensor technology. Virtual reality technology is a computer simulation system that models and renders virtual world and provides real scene experience for people under the background of digital interaction technology. This is a multi-source information fusion $3 \mathrm{~d}$ dynamic vision and 
physical behavior simulation system, which enables users to immerse themselves in the environment.

Users can not only feel the reality of the real world through the virtual reality system, but also break through the limitation of time and space, and experience the feeling that cannot be experienced in the real world. According to the degree of vertical depth experienced by the subjects, virtual imaging technology system can be divided into four categories: surface touching system, broadcast system, immersion system and remote system. The application of virtual imaging technology in the process of education teaching of ideological and political science mainly USES immersion system, broadcast system and remote system. Users break through the limitation of three dimensional thinking, get enough display feeling and interaction with digital devices and electronic devices, and can be involved in remote monitoring of the site.

Education mode of traditional ideological and political science, through static single input of paper media, has low participation and interaction of students. It is hard to effectively stimulate students' enthusiasm for research and fun in study. Although a good teacher can attract students' attention to some extent through personal enthusiasm, individual efforts alone cannot solve the overall problem. On the one hand, the number of high-quality and high-level teachers is extremely limited. On the other hand, high score is not the core value of education curriculum development in ideological politics. The purpose of education is to cultivate qualified citizens who love their country, society and people with correct world view, outlook on life and values. Therefore, it is not enough to cultivate learning interest and pursue high scores for the long-term goal of discipline construction. Virtual imaging technology can be applied to education teaching of ideological and political science in colleges and universities, which can enable students to experience specific historical subject scenes, restore the historical period where abstract theory is located, display the real appearance of historical figures, and enable students to immerse themselves in the whole country

After the founding of the People's Republic of China, China studied the Soviet model of collective indoctrination, which adopted the education model of militarization and concentration, and failed to give full play to students' ability of independent learning and active learning. The introduction of virtual imaging technology in the education classroom of ideological and political science in colleges will overturn this traditional teaching model. Breaking the limitation of time and space, students can "cross" into the classroom at any time in any life scene, work scene or even random environment. Looking around, the same classroom scene, synchronous learning students, will be presented in front of the students. Students can choose to study ideological and political courses together with their classmates who have similar research directions and mentors who have similar research topics. To a certain extent, this avoids unnecessary friction and contradiction, reduces the management cost and organization cost, and also achieves the initial goal of education. Of course, the scientific and effective exercise of this option requires the construction of virtual reality "digital space". Through the construction of this "digital space", students can not only select the research contents of their favorite ideological and political education courses according to their professional needs and research directions, but also make more like-minded friends in this virtual space. Such patterns may be in a traditional classroom mooch and lesson "micro" deva vu, but using virtual imaging technology course will far beyond traditional mu courses, because traditional mu class can break through the limitation of time and space, but can't achieve synchronization with peripheral mass of teachers and students class interaction, unable to see to understand the historical background of course. Although virtual imaging technology is still in pursuit of details, restoring reality, pursuing perfection, and sound fidelity, there are still many aspects that need to be improved and improved. However, this is only a question of time and research direction. With the help of big data update and digital media iteration, this technology can be improved and matured.

Allocate resources scientifically and optimize the cost structure. At the fifth plenary session of the 18th CPC central committee, general secretary xi jinxing put forward the five development concepts of "innovation, coordination, green, openness and sharing", which are also applicable to the promotion of virtual imaging technology in the work of education? This technology has been popularized in the field of education in college ideological and political science, and students can choose to study in non-traditional teaching environment more autonomously. However, traditional 
education teaching units only need to regularly assess the students' ideological and political education learning performance, supervise and track new teaching tasks. Family education, school education and society education will become the organic whole of "trinity" in the teaching of ideological and political education. The family, school and society jointly supervise and take charge of the ideological and political education of students, which is much better than the school unilaterally carrying out the ideological and political education of students. At this time, the role of the family in the teaching of ideological and political education will be to supervise their children to wear the virtual image technology helmet, and then complete the study of ideological and political education related courses as required by the school. In this case, the state and schools will no longer worry about the expenditure of traditional education, and the geographical differences of education resources will also be reduced. Students can enjoy high-quality education resources nationwide and overseas anywhere, and the integration of resources will greatly save the expenditure of education funds, and achieve the "supply-side reform of education resources" smoothly. For this part of saving money, it can be used to develop new course content and reward excellent students and teachers. Education has returned to the connotation of the subject and the initial target of education.

The continuous research and development and investment in virtual imaging technology will be increased to promote its continuous development and break the bottleneck of the existing technology development, so as to better apply it to education teaching of ideological and political science in colleges and universities. Although the initial research and development cost of this technology is high, once it is perfected and matured, the later changes and upgrades will be far lower than the investment required by the traditional teaching model. With a view to long-term benefits, this investment has a high cost performance

\section{The Development of VR Technology in the Practical Teaching of College Ideological and Political Education}

First, students will be more active in the study of ideological and political education theory courses. Virtual imaging technology has changed the abstract life of traditional ideological and political education courses into real touchable, vague and distant theories. It has changed the learning method of close proximity and rote memorization into immersive experience. With this artistic state of mind, the learning effect is self-evident. Secondly, for teachers, on the one hand, the application of virtual imaging technology can help teachers reduce the management burden and time cost. On the other hand, it also puts forward new requirements for the second learning of ideological and political teachers, to be comprehensive, skilled and theoretical teachers in the new era, rather than traditional "teaching and calligraphy" and "copywriting".

At present, there are still some problems in the application of virtual imaging technology in the teaching process of ideological and political education. First, there is a lack of effective management technology. Secondly, the production cost of various modeling techniques and scene rendering is relatively high. Due to the limitation of optical fiber equipment, the resolution of virtual imaging technology is not high enough. Third, the rendering resolution and light intensity of light effect may cause the retinal burn due to the absence of optical management, the multidimensional display may also cause the students' diopter deviation, and the problems of long-term wearing and eye injury are still to be solved. Therefore, virtual imaging technology can better serve the ideological and political education teaching in colleges and universities only under the supervision of relevant departments of the state and through the examination of the course teaching practice and the continuous enrichment and development in practice.

\section{Summary}

Multimedia teaching is based on multimedia technology. In the process of teaching, according to the teaching objectives and the characteristics of teaching objects, through teaching design, students can be conveyed information through various media to form a reasonable teaching process structure, 
so that students can study under the best learning conditions. Multimedia is applied in the teaching of ideological and political theory courses. Teachers can control the progress of the class and the use of various media freely as long as they are dealing with computers with the mouse in hand. Actually put forward higher request to teacher's quality, to make more successful multimedia courseware, teachers must master the teaching contents and teaching requirements, fully considering the characteristics of the students and the actual needs and psychological regularity, according to the teaching content carefully designed, comprehensive arrangement related material, to make the teaching content and animation, video clips, paste pictures, choice of music, such as one integrated mass. The application of multimedia technology in teaching, requirements of ideological and political theory course teachers must further improve their scientific and cultural quality, learn to use and grasp modern teaching devices as soon as possible, grasp the operation of the computer technology and the characteristics of multimedia and network knowledge, and use it in the teaching and scientific research. Therefore, teachers can only adapt themselves to the needs of modern education if they keep learning new knowledge, strive to improve their professional level and master modern education technology. Teachers' solid theoretical foundation and sophisticated modern teaching skills will greatly enhance the attraction and appeal of ideological and political theory courses and enhance their personality and teaching charm. The application of modern education technology, such as multimedia, is conducive to expanding students' vision, increasing the amount of teaching information in class and expanding the scale of teaching.

\section{Acknowledgements}

The College Ideological Practicing Education Research of Yunnan Province based on VR Immer sive Technology. (QN2017002)

\section{References}

[1] Li dongyang, a study on the effectiveness of education in the context of media [J] news front,2015(23):128. (In Chinese)

[2] Research on the rational interaction mechanism of education under the Internet environment of $\mathrm{xu}$ jun [J] journal of Inner Mongolia normal university: education science edition, 2014 (2) :67. (In Chinese)

[3] Zhao na, CAI hao and Yang tingting's "Internet +" effective mode day of thinking and politics education [J] China higher education, 2016 (5) :53. (In Chinese)

[4] Thoughts on the ideological and political work of young PE teachers under the new media environment of xu yuhao, li peng and wu wenfeng $[\mathrm{J}]$ school party building and thoughts education, 2014 (4) :51. (In Chinese)

[5] Research on education collaborative management of ideological and political affairs in universities in the context of dong wenbo mobile Internet [J] news front,2015 (2) :102. (In Chinese).

[6] Red flag manuscript of "micro-ideological and political" mode in universities under the background of zheng yunwang's "Internet +" [J], 2017 (3) :34. (In Chinese). 